Jarosław Hetman ${ }^{*}$

\section{W klatce interpretacji: filmowa adaptacja Caged}

DOI: http://dx.doi.org/10.12775/LC.2017.032

ilm Caged Beth Vermeer powstał $\mathrm{w}$ ramach interdyscyplinarnego projektu pt. „Remembering Henry James” [„Wspominając Henry'ego Jamesa” - przyp. J. H.] zorganizowanego przez artystkę w 2016 roku w kilku włoskich miastach, między innymi Genui. Przedsięwzięcie miało na celu kultywowanie pamięci o wielkim amerykańskim prozaiku w setną rocznicę jego śmierci poprzez liczne sympozja naukowe, dyskusje, wystawy artystyczne, spektakle teatralne i inne wydarzenia kulturalne. Obraz miał swoją premierę we Florencji, 28 lutego 2016 roku.

Caged nie jest ekranizacją noweli Henry'ego Jamesa pt. In the Cage (1898), lecz wyraźnie do niej nawiązuje, co sugeruje sam tytuł. Krótkometrażowy film opowiada o młodej kobiecie, która po studiach reżyserskich jest zmuszona pracować $\mathrm{w}$ tzw. call center, gdzie bezskutecznie próbuje sprzedawać przez telefon usługi internetowe. Odskocznię od szarej, także dosłownie, rzeczywistości stanowi jamesowski konkurs na scenorys do adaptacji filmowej, będący dla bohaterki szansą wyrwania się z klatki,

\footnotetext{
* Adiunkt w Katedrze Filologii Angielskiej Uniwersytetu Mikołaja Kopernika w Toruniu. Jego zainteresowania badawcze skupiają się na współczesnej literaturze amerykańskiej. Opiekuje się teatrem The Spinning Globe działającym przy Katedrze Filologii Angielskiej. E-mail: jarekhetman@umk.pl.
}

do której odnosi się tytuł obrazu. Zarówno pomysł na konkurs filmowy, który jest istotnym elementem fabularnym Caged, jak i sam film Caged świadczą o paradoksalnej popularności Jamesa współcześnie i, niestety, paradoksalność tę, nolens volens, wyjaśniają.

Dzieło Henry'ego Jamesa to wnikliwa analiza społeczna osadzona $\mathrm{w}$ Londynie końca XIX wieku. Główna bohaterka noweli to nienazwana młoda, inteligentna $i$ interesująca kobieta, którą niskie urodzenie i niesprzyjające okoliczności życiowe uwięziły w tytułowej klatce, czyli zaszczeblowanej budce telegrafistki, skąd za pomocą kodu Morse'a pośredniczy w relacjach osób $\mathrm{z}$ wyższych sfer. $\mathrm{Z}$ racji wykonywanej pracy ma dostęp do najskrytszych sekretów klasy społecznej, do której nie ma szans aspirować. Wiedzie zatem przyziemne, monotonne życie, planuje zamążpójście, które pozwoli jej odrobinę podnieść swój status, lecz czytelnik może się domyślać, że jej przyszłość dzielona z drobnomieszczańskim Mudgem będzie pozbawiona miłosnych uniesień, o jakich po cichu marzy. Gdy zza krat okienka poznaje Kapitana Everarda, człowieka uosabiającego wszystko to, czego brakuje jej przyszłemu mężowi, zawiązuje się akcja noweli. Wizyty wyrafinowanego, przystojnego, przystępnego $\mathrm{w}$ obyciu, ale i niedostępnego Everarda rodzą rozterki w sercu młodej kobiety, ale i skłaniają czytelnika do refleksji nad hierarchicznością społeczeństwa wiktoriańskiej Anglii. Młody kapitan chętny jest do nawiązania relacji seksualnej z bohaterką, ale tylko na warunkach hańbiących ją wedle standardów moralnych epoki.

Brak mobilności społecznej, wątek popularny $\mathrm{w}$ literaturze drugiej połowy XIX wieku, tu jest przedstawiony w sposób przewrotny, gdyż w momencie kulminacyjnym opowieści, James daje swej bohaterce niespodziewaną władzę nad Everardem, którego przyszłość zawisa na włosku wskutek 
wysłanego w przeszłości telegramu. Pozycja mężczyzny zostaje dodatkowo osłabiona, gdy na jaw wychodzi zła kondycja jego finansów. James kończy swą nowelę w sposób otwarty, acz sugestywny. Czytelnik może antycypować prawdopodobny tok wydarzeń; bohaterka wyświadczy przysługę Everardowi, lecz zwiąże się z Mudgem, który pozwoli jej na polepszenie warunków życia i da względne poczucie bezpieczeństwa. Niedopowiedzenie zamykające fabułę jest głęboko uzasadnione, gdyż dobitnie uzmysławia czytelnikowi zaznaczone $\mathrm{w}$ tytule uwięzienie głównej bohaterki. Ważąc dalsze losy młodej kobiety, to właśnie odbiorca musi sam dojść do wniosku, że wiktoriańska rzeczywistość społeczna wyklucza nie tylko miłosne spełnienie, ale i niezależność od woli mężczyzn.

Odczytanie noweli In the Cage w wykonaniu Vermeer wydaje się raczej plytkie czerpie od Jamesa nazwiska bohaterów, ale już pomija ich złożone osobowości. I tak na przykład Everard, który bohaterce In the Cage z początku jawi się niemal jako postać nadludzka (larger than life, chciałoby się dzisiaj powiedzieć), by pod koniec uczłowieczyć się poprzez swoje małostki, w filmie od razu jest raczej małym człowiekiem kierowanym przez słabo zakamuflowane popędy. W przypadku filmowego Mudge'a jest jeszcze gorzej, bo w miejscu Jamesowskiego wnikliwego portretu aspirującej klasy średniej mamy do czynienia z samym nieprzekonującym, gniewnym głosem sfrustrowanego zazdrośnika.

Najistotniejszym zaś pominięciem Vermeer zdaje się pozycja społeczna głównej bohaterki In the Cage. U Jamesa telegrafistka jest mimowolną obserwatorką życia możnych Londynu, w której ręce trafia niewspółmierna do statusu władza. U Vermeer, młoda kobieta pracująca $\mathrm{w}$ call center tylko pozornie jest uwspółcześnieniem Jamesowskiej telegrafistki, a w rzeczywistości brakuje jej moż- liwości wnikliwej obserwacji ludzi, z którymi ma do czynienia. Bohaterka zamiast pośredniczyć $\mathrm{w}$ relacjach, powtarza tylko do telefonu marketingowe frazesy, co samo w sobie jest ciekawą uwagą dotyczącą naszych czasów, lecz na poziomie fabularnym nie pełni tak złożonej funkcji jak u Jamesa. Metakinematograficzny zwrot, z którym mamy do czynienia pod koniec filmu, nie ratuje sytuacji, wręcz przeciwnie - konfunduje widza, gdyż okazuje się, że zamiast $\mathrm{z}$ uwięzioną $\mathrm{w}$ call center ofiarą kryzysu na rynku pracy, ma on do czynienia $\mathrm{z}$ aktorką grającą tę rolę. I choć można tłumaczyć ten zabieg chęcią zaskoczenia odbiorcy modnym rozwiązaniem, należy zauważyć, że wejście na poziom „meta” w kluczowym momencie opowieści nikogo już nie zaskakuje, gdyż widzieliśmy to już nie tylko w kinie awangardowym, ale i wysokobudżetowych filmach z Hollywood (takich jak ekranizacja powieści Johna Fowlesa Kochanica Francuza w reż. Karela Reisza z 1981, a także Truman Show Petera Weira z 1998 czy też Synecdoche, New York, Charliego Kaufmana z 2008 roku). $\mathrm{W}$ miejsce zburzonej interpretacji dotyczącej istotnego obecnie w Europie problemu zatrudnienia młodych ludzi nie pojawia się nowa myśl, a zamiast niej widzimy zdenerwowanego, podstarzałego Everarda łamiącego ołówek i tęsknie patrzącego w dal, prawdopodobnie za główną bohaterką filmu, która przed laty nie skorzystała z jego zaproszenia do Londynu, niby na konkurs, ale tak naprawdę do jego alkowy.

Uwięzienie młodej kobiety, choćw sposób mniej złożony niż u Jamesa, funkcjonuje również u Vermeer, ale ma wydźwięk głównie feministyczny. Otóż do zniewolenia bohaterki przyczyniają się Mudge, opresyjny, melodramatyczny i, po głosie sądząc, znacznie od niej starszy, Amerykanin, a także Everard, raz biznesmen, raz artysta, który fundując jej bilet do Londynu, wzbudza zazdrość swojej żony. Grająca główną rolę 
Zoe Pernici wyraźnie kontrastuje z próbującymi ją zniewolić starszymi mężczyznami; jest młoda, niewinna, pełna nieco naiwnej pasji. Na jej tle starania Mudge’a, a w szczególności Everarda budzą wątpliwości natury etycznej, lecz są one na tyle jednoznaczne, że nie mogą stanowić motoru napędzającego fabułę filmu. Pozytywnemu wydźwiękowi charakteryzującemu to zakończenie brakuje wyrafinowania pesymistycznej Jamesowskiej końcówki.

Zamykając wywód, chciałbym podzielić się kilkoma uwagami dotyczącymi warsztatu Vermeer, która w napisach otwierających figuruje nie jako reżyser, lecz jako kurator. Nasuwa się zatem pytanie, dlaczego artystka tak określiła swoją rolę w tworzeniu Caged. Praca kuratora rozumiana tradycyjnie polega na organizacji wystaw i wiążę się głównie z wykonywaniem zadań administracyjnych, jednak, jak zauważa Tony Godfrey, wraz z nastaniem sztuki konceptualnej coraz trudniej dokonać rozróżnienia między działaniami artystycznymi a organizacyjnymi ${ }^{1}$, lecz w przypadku Caged trudno mówić o dziele konceptualnym. Według Iana Burna zadaniem kuratora jest przedstawianie dzieł sztuki publiczności ${ }^{2}$, co, jak dodaje Robert Smithson, często wiąże się ze stawianiem artyście ograniczeń ${ }^{3}$. Dokonywanie selekcji prac trafiających na ekspozycję i określanie wymogów arty-

1 T. Godfrey, Conceptual Art, Phaidon, Londyn 1998, s. 116.

2 I. Burn, The Sixties: Crisis and Aftermath (or the Memoirs of an Ex-Conceptual Artist), [w:] Conceptual Art: A Critical Anthology, red. A. Alberro I B. Stimson, MIT Press, Cambridge 1999, s. 393.

3 R. Smithson, Cultural Confinement, [w:] Conceptual Art: A Critical Anthology, op. cit., s. 280. stycznych dla zapewnienia wystawie spójności niewątpliwie można uznać za proces twórczy, jednak nie wytrzymuje on próby porównania $\mathrm{z}$ artyzmem, jakim się musi wykazać reżyser filmu, który jest nie tyle pośrednikiem między dziełem a odbiorcą, co raczej koordynatorem poszczególnych działań twórczych składających się na ostateczny kształt obrazu. Zarówno reżyser, jak i kurator zapewniają koherencję wyrazu, lecz ten pierwszy czuwa nad spójnością pojedynczego dzieła, a rola drugiego polega na uspójnieniu szeregu niezależnych prac. Co za tym idzie, ingerencja kuratora $\mathrm{w}$ kształt wystawy zdaje się mniejsza niż wpływ reżysera na jego obraz filmowy. Określając się mianem kuratora filmu, Vermeer oddala od siebie odpowiedzialność za warstwę techniczną Caged.

Autotematyczność obrazu nie tylko plącze fabułę, lecz także silnie uwypukla jego niedostatki warsztatowe. Uważnego widza zdziwi umiejscowienie pocztówek z Londynu nie przy ekranie monitora pracującej przy komputerze bohaterki, lecz na tylnej obudowie, niewidocznej dla niej, a wyeksponowanej dla kamery. Nakręcenie sceny pierwszego spotkania biznesowego z Everardem na tle pięknej panoramy Florencji cieszy oko, lecz smuci intelekt; wszak nikt nie planuje ważnych rozmów $\mathrm{w}$ interesach na ulicy. Ciemne okulary na twarzy reżysera kręcącego scenę w szarym call center nie dodają mu wiarygodności. Jeśli Caged na poziomie „meta” mówi o sztuce filmowej, powinien lepiej nad tą sztuką panować. Ponadto uczciwiej byłoby wypowiadać się o kinematografii z pozycji reżysera, a nie kuratora. 